\title{
ELEMENTS OF FACTUAL NARRATIVE TEXT AT SOSOK SECTION IN KOMPAS NEWSPAPER 2018
}

\author{
Wida Hernawati \\ SMP Negeri 1 Cianjur \\ Email : hernawatiwida@yahoo.com
}

\begin{abstract}
Abstrak
This article discusses abaout the elements of factual narrative text at Sosok section in Kompas newspaper 2018. The results of the study of factual narrative text in sosok section is expected to be used as a source of teaching material in writing factual narrative text at school. The subject of this research is sosok section in Kompas daily newspaper 2018. The objects of this research are intrinsic elements of narrative text including background, series of events and characterizations in the sosok section. This study aims to describe background, series of events and characterizations and the results will be used to compile teaching materials in learning to write inspirational story. The method used was a qualitative research method. To collect data, the technique used was document study. The data were analyzed qualitatively. Based on the results of analysis, the results show that social background of the figure, educational background of the figure, and the natural environment in the rubric were very diverse. Social background of the figures in this rubric are from academia, artists, and common people. Their educational backgrounds also vary, from a professor to a high school graduate. The age of figures also vary, from 22 to 70 years old. Even the genders are various. The natural environment in which the figures are located is various, starting from urban areas, rural areas and even inland and disaster-prone areas. The series of events in the sosok section are interwoven chronologically and based on cause-effect.
\end{abstract}

Keywords : factual narrative, sosok section.

\section{PENDAHULUAN}

Menulis sebagai salah satu keterampilan berbahasa merupakan tahapan yang sangat sulit. Sehingga pengajaran menulis diberikan di setiap jenjang pendidikan. Dengan pemberian pengajaran menulis, diharapkan para peserta didik memiliki keterampilan menulis yang baik. Akan tetapi, pada kenyataannya pengajaran menulis di sekolah masih jauh dari harapan. Peserta didik lebih banyak diberi bekal pengetahuan bahasa dari pada dilatih menggunakan bahasa. Akibatnya, setelah mereka lulus, mereka tetap tidak mampu menggunakan bahasa Indonesia untuk berkomunikasi, baik komunikasi tulis maupun lisan.
Kurang terampilnya peserta didik dalam menulis disebabkan berbagai faktor. Pertama, peserta didik lebih banyak diberi pengetahuan dan aturan tata bahasa dan masih kurangnya latihan-latihan dalam menulis dan berbicara. Kedua, adanya realitas pembelajaran menulis di sekolah yang masih banyak menggunakan model dan strategi pembelajaran yang konvensional. Masih ada sekolah dan guru yang hanya menggunakan buku paket pelajaran sebagai satu-satunya panduan dalam pembelajaran bahasa Indonesia. Padahal seharusnya guru harus pandai memilih sebuah strategi pembelajaran yang tepat dan mampu meramu bahan ajar yang akan disampaikan kepada peserta didik agar pembelajaran menulis menjadi sebuah pembelajaran yang menyenangkan. Selain itu, 
ia juga harus dapat mengembangkan bahan ajar yang sesuai dengan fenomena yang terjadi di masyarakat, sehingga tidak terpaku pada satu sumber belajar.

Pembelajaran menulis narasi di sekolah mengharapkan terbentuknya 18 karakter peserta didik (religius, jujur, toleransi, disiplin, kerja keras, kreatif, mandiri, demokratis, rasa ingin tahu, semangat kebangsaan, cinta tanah air, menghargai prestasi, komunikatif/bersahabat, cinta damai, gemar membaca, peduli lingkungan, peduli sosial, dan bertanggungjawab). Untuk itu pembelajaran menulis narasi faktual sangatlah penting.

Inti kemampuan menulis narasi terletak pada kemampuan bercerita. Untuk itu, peserta didik harus mampu menciptakan sesuatu yang baru berdasarkan pikiran dan daya imajinasinya dalam menulis. Hal yang harus diperhatikan dalam menulis narasi yaitu, peserta didik dituntut untuk terampil berbahasa dan mengetahui tata cara penulisan, kaidah-kaidah penggunaan bahasa tulis, dan gaya penulisan tertentu agar tulisannya menarik.

Berdasarkan pengalaman peneliti serta hasil angket peserta didik dan sejumlah guru terhadap keadaan pembelajaran menulis di sekolah, diperoleh informasi bahwa motivasi dan kemampuan menulis karangan narasi peserta didik masih belum memuaskan. Hanya sebagian kecil peserta didik mencapai nilai kriteria ketuntasan minimal. Hasil karangan narasi peserta didik masih singkat (rata-rata 1-1,5 halaman), ide atau gagasan mereka kurang berkembang, kosakata yang digunakan masih terbatas, penggunaan kalimat dan organisasi tulisan narasi masih kurang terarah.

Masalah yang sering timbul dalam proses pembelajaran menulis disebabkan oleh dua faktor utama, yaitu: faktor internal dan faktor eksternal peserta didik. Faktor internal peserta didik, antara lain: (1)kurangnya motivasi ; (2)terbatasnya konsep yang dimiliki peserta didik; (3)rendahnya kemampuan menafsirkan fakta untuk ditulis; (4) kurang memuaskannya kemampuan dalam menyusun kalimat-kalimat logis dan padu. Adapun faktor eksternal, antara lain: (1) pokok bahasan menulis tidak memperoleh perhatian serius dari guru; (2) sarana, metode dan strategi pembelajaran menulis belum efektif; (3) kurangnya hubungan komunikatif antara guru dan peserta didik serta peserta didik dengan peserta didik lainnya sehingga proses interaksi menjadi vakum. Kurangnya bahan ajar yang dapat memperkaya materi ajar. Hal tersebut mengisyaratkan bahwa dibutuhkan pembenahan dalam pembelajaran menulis.

Peningkatan kemampuan menulis narasi peserta didik dapat dilakukan dengan cara penggunaan produk-produk pendidikan yang dapat menunjang pembelajaran menulis narasi. Salah satu produk itu diantaranya bahan ajar yang bisa diambil dari media cetak dan elektronik. Dalam penelitian ini, penulis mengkaji sumber belajar untuk pembelajaran menulis narasi dari rubrik Sosok dalam koran Kompas sebagai acuan dalam membuat alternatif bahan ajar.

Unsur teks narasi faktual pada rubrik Sosok dalam surat kabar Kompas tahun 2018 merupakan objek penelitian yang kemudian dijadikan sumber data. Rubrik Sosok yang terbit 288 terbitan pertahun yang terbit Senin sampai Sabtu menjadi populasi penelitian ini. Sementara yang menjadi sampel adalah sebelas terbitan yang diambil dari tanggal 2 sampai 13 Januari 2018

Teknik pengambilan sampel dalam penelitian ini dengan menggunakan purposive sampling. Menurut Sugiyono,"Purposive sampling yaitu teknik pengambilan sampel sumber data dengan pertimbangan tertentu"(2017,hlm.218-219). Sementara itu Lincoln dan Guba (dalam Sugiyono, 2017.hlm 219) menjelaskan bahwa pengambilan sampel dengan pusposive sampling tidak didasarkan perhitungan statistik. Sampel yang dipilih berfungsi untuk 
mendapatkan informasi yang maksimum, bukan untuk digeneralisasikan.'Pemilihan sampel penelitian yang berjumlah sebelas terbitan itu bertujuan mencapai ketuntasan dalam memperoleh informasi mengenai unsur-unsur narasi faktual dengan keragaman variasi yang terdapat pada rubrik Sosok dalam koran Kompas tahun 2018, bukan pada banyaknya sampel sumber data. Pemilihan sumber data disesuaikan dengan kebutuhan untuk memperoleh informasi yang diperlukan berdasarkan kriteria yang telah ditentukan. Sampel yang terpilih mewakili setiap latar (pedesaan, perkotaan, daerah terpencil dan rawan bencana), mewakili gender (laki-laki, perempuan), mewakili usia tokoh ( yang paling muda berusia 22 tahun dan paling tua berusia 70 tahun), mewakili latar belakang pendidikan dan profesi para tokoh.

Rubrik Sosok koran Kompas tahun 2018 yang menjadi sumber data yang dianalisis diambil dari terbitan tanggal 2-13 Januari 2018. Adapun judul-judul rubrik Sosok seperti berikut ini, Pengabdi Riset yang Melebur, yang menampilkan sosok Misnawi. Membumikan Hasil Riset Nanomaterial, yang menyoroti sosok Mikrajudin. Asa Membubung dari Grobogan, yang menampilkan tokoh Budi Santoso. Kunci Mitigasi di Pesisir yang menyajikan kisah tokoh Rahmat Saputra. Perjalanan Sang Desainer, menampilkan sosok Runi Palar. Pejuang dari Girime menampilkan sosok Alex Waisimon. Penyemai Bunga kering menampilkan sosok Safni Yeti. Pengabdi Lintas Batas menampilkan sosok William Jan Hekayasa. Hidup Bahagia di Daerah Bencana menyajikan sosok Mimid Suamid . Lampu Listrik Rakyat Mandiri mengupas tentang kehidupan tokoh Ujang Koswara. Dosen yang juga Sutradara, memarkan petikan perjalanan hidup Yusron Fuadi.

Berdasarkan hal itu, artikel ini akan membahas mengenai kajian unsur teks narasi faktual dalam rubrik Sosok dalam koran Kompas tahun 2018 yang meliputi unsur latar, penokohan dan rangkaian peristiwa, yang diharapkan dapat dijadikan sebagai alternatif bahan ajar pada kegiatan pembelajaran menulis di sekolah.

\section{METODE}

Metode penelitian merupakan cara ilmiah yang digunakan untuk mendapatkan data dengan tujuan dan kegunaan tertentu. Sementara itu tujuan penelitian ini untuk mendeskripsikan unsur narasi faktual berupa latar, penokohan dan rangkaian peristiwa yang terkandung dalam rubrik Sosok yang ada di surat kabar Kompas tahun 2018.

Penelitian ini menggunakan metode kualitatif, karena peneliti tidak membuat perlakuan terhadap objek penelitian tetapi hanya mengumpulkan data yang berasal dari sumber data yang ada yaitu teks narasi faktual pada rubrik Sosok dalam koran Kompas tahun 2018. Sugiyono memberikan batasan penelitian kualitatif seperti berikut ini.

"Metode penelitian kualitatif adalah metode penelitian yang berlandaskan pada filsafat postpositivisme, digunakan pada kondisi objek yang alamiah, (sebagai lawannya adalah eksperimen) dimana peneliti adalah sebagai instrumen kunci, teknik pengumpulan data dilakukan secara triangulasi (gabungan), analisis data bersifat induktif/kualitatif, dan hasil penelitian kualitatif lebih menekankan makna dari pada generalisasi”. (2017,hlm.9)

Dalam penelitian ini teknik penelitian dibedakan menjadi dua macam yaitu teknik pengumpulan data dan teknik pengolahan data.

Untuk mengumpulkan data, teknik yang digunakan adalah teknik triangulasi. Menurut Rohman, "triangulasi yakni kesesuaian antara teori, metode dan fakta."(2012,hlm.23) Sementara itu Moleong menjelaskan "bahwa teknik triangulasi adalah kegiatan yang membandingkan dan mengecekan balik derajat kepercayaan suatu informasi yag diperoleh melalui alat dan waktu yang 
berbeda".(2014, hal 157-225). Dalam penelitian ini, penerapan triangulasi dalam pengumpulan data berdasarkan studi dokumentasi, tes dan angket. Studi dokumentasi dilakukan dengan cara membaca teks narasi faktual pada rubrik Sosok. Hasil bacaan inilah yang kemudian dijadikan data penelitian yang selanjutnya akan dianalisis dan dikaji unsur-unsur narasi faktual barupa latar, plot/rangkaian peristiwa dan penokohannya.

Menurut Sugiyono dapat diikhtisarkan mengenai pengumpulan data sebagai berikut.

"Pengumpulan data dapat dilakukan dalam berbagai setting, berbagai sumber, dan berbagai cara. Bila dilihat dari settingnya, data dapat dikumpulkan pada setting alamiah dan laboratorium. Bila dilihat dari sumber datanya, pengumpulan data dapat penggunakan sumber primer dan sekunder, dan dari segi cara atau teknik pengumpulan data, maka pengumpulan data dapat dilakukan dengan obsevasi, wawancara, angket, dokumentasi dan gabungan keempatnya."(2017,hlm.224-225)

Pengumpulan data berdasarkan settingnya menggunakan cara alamiah, sedangkan berdasarkan sumber datanya penelitian ini menggunakan sumber sekunder karena sumber yang didapat melalui dokumen yaitu Rubrik Sosok dalam Koran Kompas tahun 2018.

Sementara itu berdasarkan cara atau teknik pengumpulan data, penelitian ini menggunakan teknik pustaka dan analisis dokumentasi. Teknik pustaka merupakan pengambilan dan pencarian data dari sumber tertulis oleh peneliti dalam rangka memperoleh data beserta konteks lingual yang mendukung untuk dianalisis. Pengumpulan data melalui teknik pustaka dan studi dokumentasi dilakukan dengan membaca, mencatat, mengumpulkan dan mengklasifikasi data-data dari sumber data tertulis. Selanjutnya sumber tertulis itu dibaca dengan seksama lalu dipilih tuturan yang relevan sebagai data yang dianalisis. Setelah itu, data dicatat dalam kartu data. Data-data yang telah dikumpulkan lalu diperikan sesuai dengan rumusan masalah untuk dianalisis. Sumber data melalui tahap verifikasi.

Teknik pengumpulan data dalam penelitian ini melalui proses sebagai berikut, (1) Teknik konten/ kajian isi atau teknik analisis teks, yang dilakukan dengan cara membaca dan menelaah isi teks narasi faktual pada rubrik Sosok ;(2) Teknik dokumentasi, dengan cara mengnalisis dokumen eksternal yang berupa rubrik Sosok dalam Koran Kompas tahun 2018.

Pengolahan data dilakukan dengan teknik analisis kualitatif yang bersifat induktif. Proses dan tahapan pengolahan data dengan menggunakan analisis kualitatif dapat dipaparkan sebagai berikut, (a) membaca teks narasi faktual dalam rubrik Sosok berulangulang sampai benar-benar memahaminya; (b)menganalisis unsur-unsur teks narasi faktual berupa latar, penokohan dan rangkaian peristiwanya. Menganalisis data dapat dilakukan dengan cara mereduksi data atau merangkum data, mendisplay data, dan verifikasi data. Mendisplay data yaitu penyajian data dalam bentuk uraian singkat, bagan dan hubungan antar kategori dan membuat tabel kartu data lalu menggabungkannya dalam tabel hasil analisi data. Verifikasi data, dapat berupa penarikan kesimpulan dan verifikasi. Verifikasi dilakukan dengan cara pengisian angket yang diisi oleh orang yang berkompeten. Verifikasi data menggunakan skala Guttman (Sugiyono,2017,hlm.96) "Dalam skala Guttman hanya ada dua interval yaitu "setuju" atau "tidak setuju";(c) membuat bahan ajar berupa modul yang menjelaskan unsur latar, penokohan dan rangkaian peristiwa; (d) menjawab pertanyaanpertanyaan penelitian dengan cara mengkaitkan hasil analisis dengan pertanyaan penelitian; (e) merangkum dan membuat kesimpulan dari hasil analisis. 


\section{HASIL DAN PEMBAHASAN}

Hasil temuan dari penelitian ini mencakup (1)latar atau setting yang terdapat pada rubrik Sosok dalam Koran Kompas tahun 2018. (2) Tokoh dan penokohan yang terdapat pada rubrik Sosok dalam Koran Kompas tahun 2018. (3) Rangkaian peristiwa atau jalan cerita yang terurai di rubrik Sosok dalam Koran Kompas tahun 2018 yang membangun dan membentuk karakter tokoh dalam rubrik tersebut.

Dari analisis data yang telah dilakukan dapat diuraikan bahwa Rubrik Sosok merupakan sebuah teks narasi faktual/ekspositorik yang memaparkan petikan perjalanan hidup orang-orang istimewa. Mereka istimewa karena banyak melakukan kontribusi positif bagi orangorang dan lingkungan di sekitarnya. Mereka menjadi inspirator, motivator dan pemberdaya masyarakat di sekitarnya.

Ditengah keterbatasan sarana, keterbatasan fisik, dan keterbatasan dana, tokoh-tokoh tersebut terus bekerja keras dan berjuang melakukan pengabdian untuk membantu masyarakat di sekitarnya.

Latar atau setting merujuk pada pengertan tempat, hubungan waktu, lingkungan sosial tempat terjadinya peristiwaperistiwa yang diceritakan. Menurut Stanton, "Latar adalah lingkungan yang melingkupi sebuah peristiwa dalam cerita, semesta yang berinteraksi dengan peristiwa-peristiwa yang sedang berlangsung". (2012, hlm, 35). Keberadaan latar dalam sebuah narasi sangatlah penting karena latar dapat memberikan pengaruh pada karakter seorang tokoh dan dapat membangun tone dan mood emosional yang melingkupi sang karakter.

Berdasarkan teori tersebut, setelah dianalisis ditemukan bahwa latar pada Rubrik Sosok, sangat beragam. Latar tempat pada rubrik Sosok tidak hanya terjadi di daerah perkotaan tetapi juga di daerah pedesaan, di daerah pedalaman dan terpencil, bahkan daerah rawan bencana. Sosok Mikrajudin Abdullah, Runi Palar, Safni Yeti, Ujang Koswara dan Yusron Fuadi, tinggal di daerah perkotaan. Latar daerah perkotaan tidak melenakan mereka tetapi mereka tetap berkarya dan selalu ingin bermanfaat untuk masyarakat dan lingkungan sekitarnya sesuai dengan keahlian dan bidangnya masingmasing. Berbeda dengan mereka, sosok Rahmat Saputra dan Mimid Suamid tinggal di daerah rawan bencana, sementara itu Alex Waisimon, William Jan Hekayasa, tinggal di daerah pedalaman dan daerah terpencil. Walau demikian sosok-sosok itu tidak berhenti berjuang untuk membantu memperbaiki kehidupan ekonomi masyarakat daerah terpencil dan menolong masyarakat agar terhindar dari bencana. Lain halnya dengan Misnawi dan Budi Santoso, mereka berdua tinggal di daerah perkebunan dan pedesaan. Latar tempat yang menjadi latar belakang dari setiap peristiwa yang dialami semua tokoh yang ada di Rubrik Sosok memberikan nuansa dan membangun karakter yang sangat kuat para tokohnya.

Latar belakang pendidikan para tokoh dalam rubrik Sosok beragam, ada yang berpendidikan tinggi dan merupakan kaum akademisi, seperti Misnawi, Mikrajudin Abdullah, Ujang Koswara, dan Yusron Fuadi. Ada juga yang berlatar pendidikan Menengah, seperti Budi Santoso, Rahmat Saputra, Mimid Suamid, Safni Yeti, dan Alex Waisimon. Meski berpendidikan tidak terlalu tinggi, tetapi karya mereka dan pengabdian mereka untuk masyarakat sangat besar. Selain itu ada juga Runi Palar yang merupakan lulusan sekolah kepribadian, yang berhasil mengenalkan dan mengharumkan nama Indonesia di luar negeri melalui kerajinan peraknya. Berbeda dengan tokoh lainnya, William Jan Hekayasa yang merupakan lulusan sekolah misionaris yang sepanjang kariernya ia tidak hanya bekerja sebagai pendeta tetapi ia juga membantu masyarakat pedalaman dan para narapidana agar menjadi mandiri selepas mereka selesai menjalani hukumannya. William mengerjakan semua itu tanpa memandang perbedaan. 
Latar lingkungan sosial para tokoh dalam rubrik Sosok sangat beragam. Mulai dari kalangan kampus atau kalangan akademisi seperti Misnawi, Mikrajudin Abdullah, Ujang Koswara, dan Yusron Fuadi. Ada pula yang berlatar lingkungan sosial daerah pedalaman dan daerah rawan bencana seperti Willian Jan Hekayasa, Alex Waisimon, dan Mimid Suamid serta Rahmat Saputra. Ada juga tokoh yang berlatar lingkungan sosial dunia seni seperti Runi Palar dan Safni Yeti.

Berdasarkan analisis rangkaian peristiwa, rubrik Sosok dalam Koran Kompas Tahun 2018 memiliki rangkaian peristiwa yang hampir sama. Nurgiyantoro mengatakan bahwa "salah satu unsur narasi adalah peristiwa. Peristiwa merupakan gagasan yang berwujud lakuan, gerak dan aktivitas yang lain, yang terjadi sesuai urutan waktu. Sementara itu alur atau plot adalah deretan kejadian yang mengatur hubungan peristiwa demi peristiwa agar saling berkaitan secara logis."(2010, hlm, 29). Sementara menurut Stanton dapat diikhtisarkan bahwa "Plot/ rangkaian peristiwa berisi urutan kejadian, tetapi setiap kejadian hanya dihubungkan secara sebab akibat. Alur dalam sebuah cerita memiliki alur utama dengan ciri khasnya sendiri. Dalam sebuah naratif bisa terdapat subplot-subplot yang saling berhubungan secara paralel. Dua elemen dasar yang membangun alur/ rangkaian peristiwa adalah konflik dan klimaks." (2012, hlm, 26-32). Sementera itu menurut Luxemburg dkk (dalam Nurgiyantoro, 2010: 174) mengartikan peristiwa sebagai peralihan dari satu aktivitas ke aktivitas yang lain. Peristiwa-peristiwa tersebut berfungsi sebagai pendukung plot. Kaitannya dengan pengembangan plot atau perannya dalam penyajian cerita, Luxemburg(Nuriyantoro,2010:175)

membaginya menjadi tiga jenis, yaitu peristiwa fungsional, kaitan dan acuan. Peristiwa fungsional adalah peristiwaperistiwa yang menentukan dan mempengaruhi perkembangan plot. Urutanurutan peristiwa fungsional merupakan inti cerita yang harus ada, dan apabila ada bagiannya yang dihilangkan maka akan mempengaruhi keseluruhan cerita yang menyebabkan cerita menjadi kurang logis. Peristiwa kaitan adalah peristiwa-peristiwa yang berfungsi mengaitkan peristiwa fungsional. Peristiwa acuan adalah peristiwa yang tidak secara langsung berpengaruh atau berhubugan dengan pengembangan plot, melainkan mengacu pada unsur perwatakan (Luxemburg dkk, dalam Nurgiyantoro,2010:176)

Rangkaian peristiwa yang terdapat dalam Rubrik Sosok merupakan gabungan antara rangkaian peristiwa fungsional, kaitan dan acuan. Rangkaian peristiwa yang terdapat dalam rubrik Sosok terhubung secara kronologis dan berhubungan secara paralel. Rangkaian peristiwa yang terjadi dan dialami tokoh saat ini disebabkan peristiwa yang pernah dialami oleh tokoh dimasa lalu. Hal tersebut terlihat dari peristiwa yang dialami Budi Santoso (22 th) yang berasal dari Grobogan. Ia menjadi seorang pengusaha kaki palsu dikarenakan peristiwa masa lalu yang pernah ia alami yaitu sebuah kecelakaan yang merenggut kakinya. Kecelakaan itu membuatnya menjadi seorang difabel. Keterbatasan fisiknya justru membangun semangatnya untuk dapat melakukan aktivitas yang sama dengan orang yang sempurna fisiknya. Ia berinovasi membuat kaki palsu yang dinamis dan ringan untuk membantu para difabel. Meskipun seorang difabel, ia masih dapat bermanfaat dan membantu para difabel lainnya terutama para penyandang difabel yang kurang mampu. Peristiwa fungsional digambarkan ketika Budi pada tahun 2015 hijrah ke Samarinda Kalimantan Timur untuk bekerja di sebuah bengkel alat berat. Peristiwa fungsional lainnya digambarkan ketika tahun 2016 pada saat pulang ke Grobogan, Budi mendapat musibah kecelakan ketika mengendarai motor yang mengakibatkan ia harus kehilangan kaki kirinya. Peristiwa fungsional yang lain digambarkan ketika suatu waktu pada saat Budi akan melaksanakan sholat di sebuah mesjid. Pada saat itu ia melepas kaki palsunya 
ketika hendak sholat, dan sekelompok anak melontarkan pertanyaan pada Budi,'Mengapa kaki palsunya dilepas?". Berkat pertanyaan dan peristiwa tersebut, membuat Budi berpikir untuk membuat kaki palsu yang fleksibel. Dalam cerita Sosok Budi ini, terdapat pula peristiwa kaitan, yaitu peristiwa pengalaman Budi bekerja di bengkel alat berat di Samarinda, Kalimantan Timur. Berbekal pengalamannya itulah yang menjadi dasar bagi Budi membuat kaki palsu yang fleksibel dan dinamis. Sementara peristiwa acuan terpaparkan saat budi mulai membuat kaki palsu fleksibel yang diperuntukan untuk kaum difabel yang kurang mampu, peristiwa saat Budi menularkan pengetahuannya kepada orang lain cara membuat kaki palsu. Cerita Sosok Budi Santoso tidak didominasi peristiwa fungsional. Keberadaan antara peristiwa fungsional, kaitan dan acuan hampir sama jumlahnya, sehingga cerita sosok Budi Santoso merupakan plot longgar.

Peristiwa demi peristiwa yang dialami para tokoh dalam rubrik Sosok terangkai dan terjalin secara paralel, membentuk karakter tokoh secara kuat. Konflik demi konflik yang dialami para tokohnya membentuk struktur cerita yang utuh dan dinamis. Seperti misalnya peristiwa yang pernah dialami oleh Rahmat Saputra, yang tinggal di pesisir Cipatujah, Kabupaten Tasikmalaya, Jawa Barat, yang merupakan daerah rawan gempa dan tsunami. Rahmat Saputra (45) sangat peduli dan selalu ingin membantu masyarakat di daerahnya dan ia tidak ingin berdiam diri. Segala rupa upaya ia lakukan, dari "meronda", merogoh tabungan keluarga, hingga menginisiasi pembentukan relawan penanggulangan bencana. Semua itu agar warga tanggap, bukan gagap bencana.

Konflik-konflik yang dialami oleh para tokoh dalam rubrik Sosok merupakan klimaks dari setiap perjalanan hidup yang mereka lalui, yang menjadi latar bagi perkembangan karakter, sikap dan pemikiran mereka dalam bertindak di kemudian hari. Seperti misalnya konflik yang dialami oleh Alex Waisimon dengan warga Kampung Yenggu, Papua, tanah kelahirannya, yang menentang Alex yang ingin menghentikan pembalakan liar di hutan. Meski Alex sempat kecewa dan sempat pergi ke Bali dan meninggalkan Papua, namun ia pantang menyerah. Ia kembali lagi ke Papua ke Rhepang Muaif. Disana ia akhirnya berhasil menghentikan pembalakan liar di hutan bahkan berhasil mengembangkan daerah tersebut menjadi hutan lindung bagi habitat hewan endemik termasuk burung cendrawasih dan menjadikannya sebagai destinasi wisata bagi para wisatawan luar dan dalam negeri yang ingin melihat dan berfoto dengan burung cendrawasih. Dengan adanya pengembangan daerah Rhepang Muaif menjadi daerah wisata maka pertumbuhan ekonomi masyarakatnya pun meningkat.

Tak berbeda dengan Alex Waisimon, Safni Yeti pun pernah mengalami konflik dalam perjalanan hidupnya. Konflik ketika Safni Yeti pada tahun 2008 mengalami pemutusan hubungan kerja. Berbekal uang pesangon, Safni yang dulu bekerja di pabrik kerajinan tangan melihat peluang untuk membuat kerajinan bunga kering dari bahan yang tak terpakai yang ada di sekitarnya, seperti kolobot jagung. Dengan bahan yang asalnya tidak terpakai itu akhirnya Safni Yeti dapat mengembangkan menjadi barang kerajinan yang bernilai ekonomi tinggi, terutama di pasaran luar negeri, terlebih pasar Asia dan Eropa. Ia kemudian mengajarkan para istri petani jagung serta anak-anak mereka dan memberikan pelatihan kepada ibu rumah tangga agar bisa produktif memberikan penghasilan tambahan dari kerajinan bunga kering. Bagi Safni, benda yang dianggap sampah masih bisa dimanfaatkan. Usia barang akan bisa bertahan makin lama jika diolah menjadi barang berekonomi tinggi. Makin banyak orang menggeluti bisnis bunga kering, makin banyak pula sampah bisa dikurangi. Akibat kiprahnya itu, nama Indonesia pun bisa makin dikenal sebagai produsen kerajinan yang ramah lingkungan. 
Berdasarkan uraian mengenai rangkaian peristiwa, rubrik Sosok pada Koran Kompas pada umumnya menggunakan plot longgar, karena peristiwa fungsional yang terdapat dalam rubrik Sosok tidak lebih dominan keberadaannya dibandingkan dengan peristiwa kaitan dan acuan. Keberadaan jenis peristiwa-peristiwa itu dalam rubrik Sosok seimbang.

Salah satu unsur narasi lain yang juga penting yaitu adanya pengisahan tokoh dan penokohan cerita yang bergerak dalam rangkaian perbuatan. Penokohan sendiri menurut Jones (dalam Nurgiyantoro,2010:247) mengatakan bahwa penokohan adalah pelukisan gambaran yang jelas tentang seseorang yang ditampilkan dalam cerita. Pengisahan tokoh cerita terlibat dalam suatu peristiwa atau kejadian. Tindakan, peristiwa, dan kejadian itu disusun bersama-sama sehingga mendapatkan kesan tunggal. Menurut Nurgiyantoro(2010;248)," penokohan terbagi menjadi dikotomi bentuk dan isi. Tokoh, watak, dan segala emosi yang dikandungnya itu adalah aspek isi, sedangkan teknik perwujudannya adalah aspek bentuk." Sementara itu menurut Stanton dapat diikhtisarkan bahwa "penokohan atau karakter tokoh tergambar dalam dua konteks. Konteks pertama, karakter tokoh dimunculkan dalam cerita secara langsung/eksplisit. Konteks kedua, karakter tergambar secara implisit yang terlihat dalam dialog dan adegan."(2012,hlm.33-35)

Dari pendeskripsian perilaku para tokoh dalam rubrik Sosok pada Koran Kompas, terlihat bahwa karakter-karakter tokohnya digambarkan secara implisit dan eksplisit. Setiap tokoh memiliki dimensi karakter atau watak tersendiri. Penokohan sebagai salah satu pengembang cerita dapat dikaji keterjalinannya dengan unsur-unsur yang lain sehingga membentuk totalitas.

Tokoh-tokoh yang ditampilan di Rubrik Sosok merupakan orang-orang istimewa, yang datang dari berbagai kalangan, beragam usia, dan berbagai latar belakang pendidikan dan agama. Orang-orang yang memiliki jiwa sosial yang tinggi, yang peduli dan sangat memperhatikan lingkungan dan masyarakat sekitarnya.

Tokoh-tokoh Rubrik Sosok memiliki karakter yang kuat, tangguh, dan pantang menyerah. Bahkan mereka rela berkorban, mengeluarkan dana pribadi untuk membantu masyarakat. Mereka banyak membantu orang-orang di sekitarnya, tidak memandang suku,ras, agama, dan status sosial.

Sebutlah William Jan Hekayasa, yang tidak lelah memperjuangkan kesejahteraan masyarakat dan melakukan banyak hal untuk kemanusiaan di Desa Huanakota, Kabupaten Seram bagian barat,Maluku Tengah. Ia melakukan pekerjaannya melampaui tugasnya sebagai pendeta. Ia melayani warga pedalaman, membangun kehidupan para narapidana yang berbeda-beda agamanya, dan ikut memadukan harmoni keagamaan di daerah bekas konflik. William Jan Hekayasa merupakan pribadi yang unik dan kontras. Banyak orang yang tak menyangka pria berkulit agak gelap, tubuh berisi dengan tinggi 175 sentimeter, bertato, serta rambut terurai hingga punggung itu adalah seorang pendeta. Sepanjang kariernya, ia membantu masyarakat pedalaman hingga narapidana tanpa memandang perbedaan. Perjuangannya untuk membantu masyarakat pedalaman di desa Huanakota ditunjukkannya dengan memodifikasi mobil pemberian ayahnya menjadi mobil bak terbuka yang dipakai sarana transportasi masyarakat setempat untuk menjual hasil kebunnya. Tidak hanya sampai disitu saja, ia juga menginisiasi jam belajar anak-anak di desa tersebut sehingga menjadi kebiasaan untuk belajar dari jam 19.00-21.00. William juga menginisiasi diluncurkan album lagu Salam-sarane. Dalam budaya Maluku, Salam merupakan sebutan bagi umat Islam, sedangkan Sarane untuk umat Kristiani. Lagu-lagu rohani Kristen ikut dinyanyikan lokal Maluku beragama Islam. 
William hanya ingin menyebarkan pesan harmoni dalam perbedaan. Baginya, Maluku yang pernah dilanda konflik sosial bernuansa agama belasan tahun silam itu kini sudah bangkit merajut persaudaraan.

William telah melakukan banyak hal untuk kemanusiaan di Maluku yang jauh melampaui tugasnya sebagai pendeta. Melayani warga pedalaman, membangun kehidupan para narapidana, dan ikut memadukan harmoni di deerah bekas konflik. Tak berlebihan jika ia disebut sang pengabdi lintas batas.

Penggambaran sikap, tingkah, gerak dan aktivitas yang dilakukan oleh William, menunjukkan karakternya secara implisit. Namun penggambaran watak atau karakter William terpaparkan juga secara eksplisit, seperti penggambaran karakter William Jan Hekayasa yang tergambar dari komentar Herman Neite (55), tokoh masyarakat Hukuanakota. "Dia mengerti dan sangat peka dengan kondisi orang. Dia bekerja nyata, tidak hanya khotbah."

Sosok yang lain juga yang memiliki karakter yang istimewa adalah sosok Budi Santoso. Ia seorang difabel dengan keterbatasan fisik, tetapi masih mampu menolong orang lain sesama difabel. Ia mampu memberikan pengharapan kepada para penyandang difabel yang kurang mampu agar tetap dapat beraktivitas seperti orang normal dengan memberikan kaki palsu buatannya secara gratis.

Budi Santoso yang menyandang disabilitas sejak setahun terakhir, justru membuat hidupnya lebih bermakna. Ia merasakan langsung bagaimana terbatasnya aktivitas ketika seseorang tidak memiliki kaki. Dari situ, tercetus ide untuk membuat kaki palsu yang dinamis. Ia ingin orang yang anggota badannya sebagian buntung tetap punya mimpi yang membubung.

\section{SIMPULAN}

Berdasarkan hasil kajian unsur latar, penokohan dan rangkaian peristiwa, dalam rubrik Sosok pada Koran Kompas 2018 maka dapat disimpulkan seperti berikut ini.

Rubrik Sosok menampilkan orang-orang pemberani. Sosok-sosok unik dengan kreatifitas nyeleneh, orang yang berani keluar dari zona nyaman dan cenderung nekat, orang-orang yang memiliki kiprah besar tidak hanya di dalam negeri tetapi juga di luar negeri. Pencipta-pencipta hal-hal sederhana yang dampaknya luar biasa. Orang-orang yang berprestasi dan kreatif walau memiliki keterbatasan fisik. Orang-orang yang mampu memberdayakan kaum lemah, orang-orang yang memiliki semangat pengorbanan tinggi, orang-orang yang menjadi pelopor, orangorang yang memiliki karakter mulia. Orangorang yang dengan tulus mengabdikan dirinya untuk masyarakatnya.

Latar pada Rubrik Sosok dalam koran Kompas tahun 2018, sangat beragam. Latar tempat pada rubrik ini tidak hanya terjadi di daerah perkotaan tetapi juga di daerah pedesaan, daerah pedalaman dan daerah terpencil, bahkan daerah rawan bencana. Latar tempat yang menjadi latar belakang dari setiap peristiwa yang dialami semua tokoh yang ada di Rubrik Sosok memberikan nuansa dan membangun karakter yang sangat kuat para tokohnya. Latar belakang pendidikan para tokoh para Rubrik Sosok ada yang berpendidikan tinggi dan merupakan kaum akademisi. Ada juga yang berlatar pendidikan Menengah. Meski berpendidikan tidak terlalu tinggi, tetapi karya mereka dan pengabdian mereka untuk masyarakat sangat besar. Latar lingkungan sosial para tokoh yang beragam, mulai dari kalangan kampus atau akademisi seperti Misnawi, Mikrajudin Abdullah, Ujang Koswara, dan Yusron Fuadi. Sampai tokoh yang berlatar lingkungan sosial daerah pedalaman dan daerah rawan bencana seperti Willian Jan Hekayasa, Alex Waisimon, dan Mimid Suamid serta Rahmat Saputra, yang berpendidikan hanya sampai sekolah menengah saja. Selain itu terdapat 
juga tokoh yang berlatar lingkungan dunia seni seperti Runi Palar dan Safni Yeti.

$\begin{array}{rcr}\text { Rangkaian } & \text { peristiwa yang terdapat } \\ \text { dalam Rubrik } & \text { Sosok hampir semua }\end{array}$
merupakan alur campuran. Rangkaian peristiwa yang terjadi dan dialami tokoh saat ini disebabkan peristiwa yang pernah dialami tokoh dimasa lalu. Rangkaian peristiwa terjalin secara kronologis sebab-akibat. Rangkaian peristiwa yang dialami membangun karakter tokoh dengan kuat.

Sedangkan karakter tokoh dan penokohan dalam rubrik Sosok koran Kompas tahun 2018 dipaparkan secara implisit, walaupun ada juga yang dideskripsikan secara eksplisit.

Penokohan sebagai salah satu unsur narasi dapat terkait bersama unsur-unsur lainnya sehingga membentuk totalitas dalam cerita. Penokohan dapat terkait dengan latar dan rangkaian peristiwa. Plot atau rangkaian peristiwa sekadar merupakan sarana untuk memahami perjalanan kehidupan tokoh. Penokohan dan pemplotan/ rangkaian peristiwa saling pengaruh mempengaruhi satu sama lainnya. Plot/alur/rangkaian peristiwa adalah apa yang dilakukan tokoh dan apa yang menimpanya. Ada kejadian demi kejadian, ketegangan, demi ketegangan konflik dan sampai pada klimaks.

Teks narasi mengandung unsur latar, penokohan dan rangkaian peristiwa. Berdasarkan hasil analisis yang telah dilakukan pada Rubrik Sosok, terdapat latar, penokohan dan rangkaian peristiwa seperti yang telah dipaparkan oleh para ahli, dapat disimpulkan bahwa Rubrik Sosok dalam Koran Kompas, merupakan bentuk teks narasi faktual/ekspositoris karena memaparkan penggalan perjalanan hidup para tokohnya.

Berdasarkan hasil kajian terhadap unsur narasi faktual dalam rubrik Sosok pada Koran Kompas tahun 2018, dapat disimpulkan pula bahwa rubrik Sosok ini dapat dikembangkan dan dimanfaatkan sebagai bahan ajar di sekolah. Hal tersebut akan sangat membantu guru sebagai pendidik dalam pembelajaran menulis narasi. Modul yang sudah disusun sudah mendapat uji validasi dan penilaian dari guru mata pelajaran bahasa Indonesia. Dari beberapa angket yang disebar pada responden guru mata pelajaran bahasa Indonesia, diperoleh hasil bahwa Rubrik Sosok dalam Koran Kompas tahun 2018 layak untuk diimplementasikan menjadi bahan ajar dalam pembelajaran menulis narasi faktual . 


\section{DAFTAR PUSTAKA}

Anwar,K.(2018)."Membumikan Hasil Riset Nanomaterial”, Kompas. Rabu, 3 Januari 2018. hlm. 16

Ashri,AF.(2018).’Kunci Mitigasi di Pesisir”, Kompas. Jumat, 5 Januari 2018. hlm.16

Basyari,I.(2018).” Penyemai Bunga Kering”, Kompas. Selasa, 9 Januari 2018. hlm. 16

Costa,F M L.(2018).’Pejuang dari Girime”, Kompas. Senin, 8 Januari 2018. hlm.16.

Helmy,C.(2018)."Hidup Bahagia di Daerah Bencana”, Kompas. Kamis, 11 Januari 2018. hlm. 16

Herin,FP.(2018).’Pengabdi Lintas Batas”, Kompas. Rabu, 10 Januari 2018. hlm.16

Herusansono,W.(2018).”Asa Membubung dari Grobogan”. Kompas. Kamis, 4 Januari 2018. hlm.16

Muhtadi,D.(2018).’Lampu Listrik Rakyat Mandiri”. Dalam Kompas. 12 Januari 2018. Jakarta

Moleong, L J. (2014). Metodologi penelitian kualitatif. Bandung : PT Remaja Rosdakarya.

Nurgiyantoro,Burhan.(2010).Teori Pengkajian Fiksi.Yogyakarta : Gadjah Mada University Press.

Rohman,S.(2012).Pengantar metodologi pengajaran sastra.Jogjakarta : Ar-Ruzz Media

Putranto,ABA dkk.(2018).’Pengabdi Riset yang Melebur”,Kompas. Selasa, 2 Januari 2018. hlm. 16

Stanton,Robert.(2012).Teori Fiksi.Yogyakarta : Pustaka Pelajar.

Sugiyono. (2017).Metode penelitian (kuantitatif,kualitatif, dan $R \& D$ ). Bandung : Alfabeta.

Sulistyowati,A.(2018).”Perjalanan Sang Desainer", Kompas, Sabtu, 6 Januari 2018. hlm.16

Sumantri,BS.(2018).”Dosen yang juga Sutradara”.Kompas. Sabtu, 13 Januari 2018. hlm.16 